Analytical Analysis for the Impact of Fair Value Accounting on Audit ...

Aya Ashraf Mahmoud Mohammed

\title{
Analytical Analysis for the Impact of Fair Value Accounting on Audit Quality Practices Aya Ashraf Mahmoud Mohammed
}

\section{Abstract}

Purpose: The purpose of this research is to investigate the impact of fair value accounting on audit quality practices.

Design/Methodology/Approach: The paper's finding is based on an empirical study through a questionnaire created from the literature and distributed among 209 external auditors and 76 financial statements preparers of the publicly traded companies listed in the Egyptian Stock Exchanges. The questionnaire's reliability was tested using Cronbach's alpha coefficients.

Findings: The results show that there is a significant positive impact of fair value measurements complexity on audit quality practices.

Key words: fair value measurements, audit quality practices, professional skepticism, due professional care.

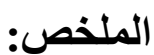

الغرض: الغرض من هذا البحث هو التحقيق في تأثيرمحاسبة القيمة العادلة على التى ممارسات جودة المر اجعة. التصميم / المنهجية / المنهج: يستند اكتشاف البحث إلى إلى دراسة تجريبية من خلال

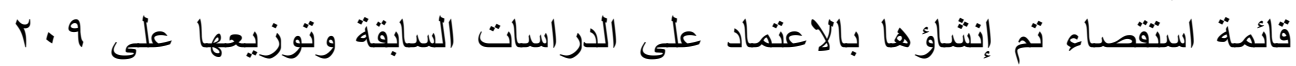

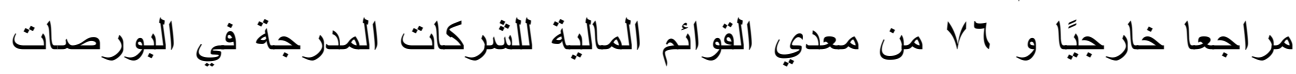
المصرية. تم اختبار موثوقية الاستبيان باستخدام معاملات ألفا كرونباخ. 
Analytical Analysis for the Impact of Fair Value Accounting on Audit ...

Aya Ashraf Mahmoud Mohammed

النتائج: تظهر النتائج أن هناك تأثيرًا إيجابيًا مهمًا لصعوبة قياسات القيمة العادلة على ممارسات جودة المر اجعة.

الكلمات الدالة: قياسات القيمة العادلة،ممارسات جودة العيرة المراجعة، الثك المهنى و العناية المهنية.

\section{Research Idea}

In the beginning of the 2000s, the concern about fair value accounting has risen because among the preferences of investors. Hence, fair value is the most preferred basis for valuation due to their greater relevance than historical cost (Cannon and Bedard, 2017). The recent financial crisis in 2008 has turned the spotlight on fair value accounting (Palea, 2014). Where the management's responsibility is to establish an accounting and financial reporting process in determining the fair value measurements and making assumptions about future conditions whose outcomes are uncertain and subject to change over time. As a result, level 3 fair values based on management assumptions are susceptible to estimation error, management discretion and manipulation.

Therefore, external auditor is needed to give the users confidence about fair value information and ensure the degree on which financial statement users can rely on financial statements (Christensen et al., 2016). The fair value measurements (FVMs) are challengeable for auditors due to their complexity, subjectivity, lack of verifiable data and dependence on management assumptions and valuations techniques (Cannon and Bedard, 2017). 
Analytical Analysis for the Impact of Fair Value Accounting on Audit ...

Aya Ashraf Mahmoud Mohammed

Thus, after blaming fair value accounting for being the reason for the financial crisis, the attention has risen towards auditing fair value measurements. Moreover, developing countries are characterized by the presence of inactive markets of most assets and liabilities (Abdullatif, 2016). Therefore, auditors are driven to perform some practices as a way to increase the relevance of $\mathrm{FV}$ estimates and to restore the public trust in the auditing profession (Abdallah, 2018).

This research develops empirical research to explore the impact of fair value measurements on audit quality practices. Since research in the area of auditing fair value measurements is critical and that encourage the researcher to develop this research to understand FVA and the process of auditing FVMs and identifying major challenges auditors face and how these challenges force auditors to reshape their practices to suit with the complexity of FVMs. This research will focus on how the financial instruments measured at fair value can affect the following audit quality practices: (professional skepticism and due professional care).

\section{Research Objective}

1. Examining whether fair value measurements complexity significantly influence audit quality practices.

2. Investigating whether fair value disclosure significantly affects audit quality practices. 
Analytical Analysis for the Impact of Fair Value Accounting on Audit ...

Aya Ashraf Mahmoud Mohammed

\section{Research Hypotheses}

H1: Fair value measurements complexity significantly and positively affects audit quality practices.

H2: Fair value disclosure significantly and positively affects audit quality practices.

\section{Research Importance}

\subsection{From the Academic Point of View}

This research extents the literature on fair value accounting by explaining the measurements of fair-valued financial instruments in Egypt as an example of a developing country. Also, it provides a better explain for four main types of audit quality practices. Therefore, the research comes in the favor of academic researchers, regulators and financial standards setter to improve their understanding for auditing fair value accounting and standards related to fair value accounting.

\subsection{From the Empirical Point of View}

This research is particularly important after the occurrence of the financial crisis. Hence, the auditors were accused for being careless while auditing fair value. The complexity and difficulty in measuring financial instruments. Thus, auditors have to pay more attention for fair value. Therefore, this research will be useful and provide guidance for both financial statements preparers and auditors because it provides some practices auditors should follow when they are dealing with fair measurements. 
Analytical Analysis for the Impact of Fair Value Accounting on Audit ...

Aya Ashraf Mahmoud Mohammed

\section{Research Methodology}

To achieve the main objective, a self-made questionnaire is used in this research. The sample size is 285 distributed among 209 external auditors and 76 financial statements preparers of the publicly traded companies listed in the Egyptian Stock Exchanges to know their evaluation concerning the complexity of fair value measurements, whether it affects audit quality practices. This questionnaire's reliability was tested using Cronbach's alpha coefficients. The questionnaire is designed based on the Likert scale model with five columns of choice.

\section{Research Outline}

Section One: The Effect of Fair Value Accounting on Audit Quality Practices.

Section Two: Empirical Study.

Section Three: Conclusion.

Section One: The Effect of Fair Value Accounting on Audit Quality Practices.

\section{Fair Value Measurements of Financial Instruments under IFRS 9}

IFRS 9 introduces the bases to determine the treatment for the financial instruments' classifications and measurements through two criteria:

\section{The First Criteria: Business Model}

Business model refers to the way the entity can manage its financial assets in generating cash flows. The IFRS 9 divided 
Analytical Analysis for the Impact of Fair Value Accounting on Audit ...

Aya Ashraf Mahmoud Mohammed

business models into three categories: held to collect, collect and sell and for selling as residual category (Volarević and Varović, 2018).

\section{The Second Criteria: The Contractual Cash Flow} Characteristics

Financial instruments with contractual cash flows make solely payments of principal and interest (SPPI) on the outstanding principal amount.

Based on the two criteria discussed above, IFRS 9 classifies financial assets into one of the following three categories.

1. Financial Assets Measured at Amortized Cost (AC)

Financial assets in the $\mathrm{AC}$ category are initially recognized at fair value and later measured at $\mathrm{AC}$, when the following two conditions are met (IFRS 9, 4.1.2):

a. The asset is hold to collect business model.

b. The asset's contractual terms give rise on specified dates to cash flows that are solely payments of principal and interest on the principal amount.

2. Financial assets measured at Fair Value through other Comprehensive Income

Financial assets in the FVOCI category are originally recognized and measured at fair value but the changes, when the following two conditions are met (IFRS 9, 4.1.2A):

a. hold to collect and sell business model. 
Analytical Analysis for the Impact of Fair Value Accounting on Audit ...

Aya Ashraf Mahmoud Mohammed

b. The asset's contractual terms give rise on specified dates to cash flows that are solely payments of principal and interest on the principal amount.

3. Financial assets are measured at fair value through profit and $\underline{\text { loss }}$

Financial assets that do not meet the conditions for classification for being measured at either AC or FVOCI are measured at FVPL.

\section{Fair Value Disclosure of Financial Instruments under IFRS 7}

Entities are required by IFRS 7 to provide disclosures that enable users to evaluate the important of financial instruments to the entities' financial position, performance, the nature of risks arising from financial instruments and how the entity manage those risks (Lau, 2016). Additionally, determine whether financial instruments relate to derivatives or non-derivatives. Moreover, it provides two main types of disclosure. First, an entity must provide information about the financial instruments: balance sheet disclosures, income statement disclosures, hedging disclosures, fair value disclosures and other disclosures (IASB, 2008; Tahat et al., 2016). Second, an entity must provide information about the nature and extent of the risks from using of the financial instruments including:

1. Qualitative disclosures describe risks for financial instruments' types, management's objectives and policies, how 
Analytical Analysis for the Impact of Fair Value Accounting on Audit ...

Aya Ashraf Mahmoud Mohammed

managers can manage those risks and changes from prior period.

2. Quantitative disclosures describe risks from using of the financial instruments including all types of risks: credit risk, liquidity risk and market risk (IASB, 2008; Tahat et al., 2016).

\section{Overview of Audit Quality Practices}

With the dynamic changes in the professional auditing environment, audit firms have to improve their practices and increase the quality of audit process in order to reduce the audit failures (Bedard et al., 2010). Nwanyanwu (2017) defines audit quality practices as "procedures established by auditors to ensure that financial reports communicate relevant and reliable information to members of an entity and the public". The practices of audit quality take many forms including: professional skepticism and due professional care which will be discussed in the following sub-sections.

\subsection{Professional Skepticism}

Professional skepticism plays a critical role in audit practice (Feng and Li 2014). Additionally, it is the cornerstone of audit quality and an important ingredient that guarantees high audit quality (Chiang, 2016; Hoos et al., 2019). Skeptical auditors are likely to question the reliability and usefulness of any evidence and information they encounter (Cruz et al., 2020). The appropriate levels of skepticism increase the likelihood that 
Analytical Analysis for the Impact of Fair Value Accounting on Audit ...

Aya Ashraf Mahmoud Mohammed

material misstatements detected, which will be reflected in promoting audit quality and shareholder confidence.

Professional skepticism refers to the attitude where auditors are suspicious in nature until they obtain sufficient information or evidences and is driven behaviorally to report fraud (Hussin et al., 2017). Moreover, Nelson (2009) suggest a model for skepticism by dividing it into two views : "neutral" view which involves an open-minded attitude and that the management are neutral neither totally honest nor totally dishonest and "presumptive doubt" view which involves that auditors when conduct audit process keep in mind the possibility of a material misstatement due to fraud (Popova, 2013).

Based on the abovementioned, it can be concluded that auditors are supposed to maintain skeptical attitude through practicing a mix between trust with their clients to perform an efficient audit and suspicions through gathering and evaluating evidence throughout audit process till they are satisfied with evidences collected and that the financial statements are free from any fraud. Additionally, skepticism is one of the major ingredients that ensure the quality of audit.

\subsection{Due Professional Care}

Due professional care is the foundation of auditing and puts a primary responsibility on fraud detection (Rezaee, 2004; Nearon, 2005). Hence, it concerns with what auditors do and how well they do it and critical in establishing public confidence in 
Analytical Analysis for the Impact of Fair Value Accounting on Audit ...

Aya Ashraf Mahmoud Mohammed

business. Further, auditors who apply due professional care are easier to detect fraud in the entities being audited. Furthermore, the key of successful auditor is maintaining the attitude of due professional care in conducting the audit, which help auditors in understanding: the importance of auditing to the clients in maintaining the trust of the clients, the importance of prioritizing work experience to improve auditor's expertise and the importance of prioritizing ongoing professional education to improve audit skills (Akbar and Suraida, 2017).

From the abovementioned, it is concluded that due professional care refers to whether auditors are properly planned, supervised, reviewed, work seriously, explain the rational for their decisions, evaluate audit evidence objectively and more dedicated to their job. Additionally, due care is the maximum use of the auditor's skills and knowledge in a good manner and that increase the quality of audit process.

\section{The Relationship between Fair Value Measurements and Audit Quality Practices}

FV measurements for financial instruments forced auditors to perform audit quality practices to encounter its difficulty.

With the growing complexity of applying the FVA, the role played by auditors became critical in providing necessary assurance to capital markets. Generally, auditors do not face very serious issues while auditing Level 1 fair values on account of the existence of objective evidences. But problems escalate.

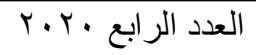

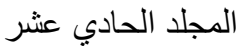


Analytical Analysis for the Impact of Fair Value Accounting on Audit ...

Aya Ashraf Mahmoud Mohammed

Level 3 valuations that represent management's opinion of the market dynamics that leads to the risks of errors or intentional managerial bias in the selection of an appropriate model and in the assumptions used in estimation (Singh and Doliya, 2015).

Skepticism throughout the audit process increases not only the likelihood of detecting fraud but also reduces the risk that fraud will be attempted (Nelson, 2009). Furthermore, concerns over professional skepticism exercised by auditors are increasing due to lack of sufficient and appropriate evidence gathered to assure management's assumptions when dealing with complex accounting such as impairment and fair value measurements (Stevens et al., 2019). The amounts of estimates are uncertain and supporting evidence is not concrete (Bratten et al., 2013). Additionally, high professional skepticism allow auditors to increases the quantity of audit work performed and expand their searches and assess a greater likelihood of fraud and more weight to fraud evidence especially complex, subjective or highly judgmental accounts (Nelson, 2009).

Both accountants and auditors must illustrate due care during establishing the FV estimates (Aouni et al., 2017). Exercising due care mean to be careful for every detail in the financial statements and collect sufficient evidence for fair value measurements and disclosure. Auditor negligence can lead to the failure in audit process not only from misstated financial statements but also there can be circumstances in which clients or

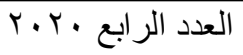

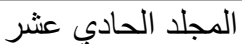


Analytical Analysis for the Impact of Fair Value Accounting on Audit ...

Aya Ashraf Mahmoud Mohammed

other stakeholders suffer losses while conducting the audit especially for fair value estimates (Maksymov and Nelson, 2017). Further, the auditors' negligence means that auditors do not exercise sufficient due care.

From the above, it is concluded that the nature of fair value accounting characterize by the difficulty of verifiability. Additionally, the complexity associated with lack of objective data and high level of uncertainty involved with particular estimations and managements' bias lead to the need for additional tests and evidence. Therefore, auditors are forced to perform certain practices to decrease the severe effect of fair value.

\section{Section Two: Empirical Study}

\section{Introduction}

The purpose of this research is to investigate the effect of fair value measurements for financial instruments on audit quality practices. According to the foregoing, the researcher relies on testing the direct effects between the variables on the statistical methods that fit with these variables and the size of the sample. Therefore, the researcher used the Statistical Package for the Social Science (SPSS V.25).

\section{Response Rate}

The sample was represented by external auditors and financial statements preparers of entities listed on the Egyptian Stock Exchange through the websites was (285) questionnaires. 
Analytical Analysis for the Impact of Fair Value Accounting on Audit ...

Aya Ashraf Mahmoud Mohammed

The descriptive analysis of the results found that the response rate of external auditors was (73\%). While the response rate of the research sample from financial statements preparers in entities listed on the Egyptian Stock Exchange was (27\%).

\section{Descriptive Analysis of the Research}

\subsection{Descriptive Analysis of Variables}

The researcher conducts a descriptive analysis of the data using the program (SPSSV.25). In order to identify the shape and nature of the data and also identify the values of means and standard deviations of the research's variables.

Regarding to fair value measurements complexity variable: it has a relative importance among the research's sample. Where the arithmetic mean of the variable is (4.52), which is higher value than the general arithmetic mean of the five-point Likert scales (3). Hence, the value of the arithmetic mean of the variable came in the first order from the research's sample. This means that the research's sample has a relative interest in this variable with percentage of agreement among the opinions of the research sample.

Regarding to Audit quality practices variable: it has relative importance among the research's sample. Where the arithmetic mean of the variable is (3.93), which is higher value than the general arithmetic mean of the five-point Likert scales (3). This means that research's sample believes that audit quality practices 
Analytical Analysis for the Impact of Fair Value Accounting on Audit ...

Aya Ashraf Mahmoud Mohammed

are a major factor within the entities listed in the Egyptian Stock Exchange.

Table (1) Descriptive analysis of variables $(n=285)$

\begin{tabular}{|l|c|c|c|}
\hline \multirow{2}{*}{ Variables } & \multicolumn{3}{c|}{ Descriptive Analysis of } \\
\cline { 2 - 4 } & Mean & S.D. & C.V. \\
\cline { 2 - 4 } & 4.52 & .614 & $13.6 \%$ \\
\hline Fair value measurements complexity & 3.93 & .543 & $13.8 \%$ \\
\hline Audit quality practices & 4.08 & .606 & $14.8 \%$ \\
\hline Fair value disclosure &
\end{tabular}

\section{Source: Results of statistical analysis (SPSS)}

Note: S.D. = Standard deviation, C.V.= Coefficient of

\section{variance}

It is concluded from the previous results that, all the variables have relative importance. Therefore, the answers of the research's sample about the variables tend to be positive. As a result, this is reflected in the statistical results during testing the hypotheses.

\subsection{Normal Distribution}

Table (3) Normal Distribution for Variables

\begin{tabular}{|c|c|c|c|c|c|c|}
\hline \multirow{2}{*}{ Variables } & \multicolumn{3}{|c|}{ Kolmogorov-Smirnov } & \multicolumn{3}{c|}{ Shapiro-Wilk } \\
\cline { 2 - 7 } & Statistics & d.f. & Sig. & Statistics & d.f. & Sig. \\
\hline $\begin{array}{c}\text { Fair value } \\
\text { measurements } \\
\text { complexity }\end{array}$ & .222 & 285 & 0.000 & .787 & 285 & 0.000 \\
\hline $\begin{array}{c}\text { Audit quality } \\
\text { practices }\end{array}$ & .229 & 285 & 0.000 & .876 & 285 & 0.000 \\
\hline $\begin{array}{c}\text { Fair value } \\
\text { disclosure }\end{array}$ & .176 & 285 & 0.000 & .848 & 285 & 0.000 \\
\hline
\end{tabular}

Source: Results of statistical analysis (SPSS) 
Analytical Analysis for the Impact of Fair Value Accounting on Audit ...

Aya Ashraf Mahmoud Mohammed

From the previous table it is concluded that, all the values related to the variables are significant at the level of $5 \%$. Where the values less than the level of significance indicates the need to use Non - Parametric Methods while examining the hypotheses of the research.

\section{Hypothesis Test}

H1: fair value measurements complexity significantly and positively affects audit quality practices.

It is clear from this hypothesis that there are two types of variables, namely:

Fair value measurements complexity

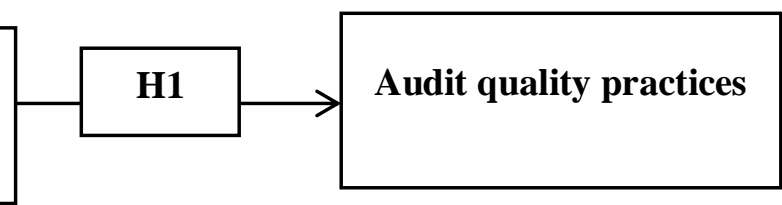

A: Direct relationships between variables: the statistical results reached the following Correlation matrix:

Table (4) Correlation Matrix between Fair value measurements complexity and Audit quality practice_( $\mathrm{n}=\mathbf{2 8 5}$ )

Correlations

\begin{tabular}{|c|c|c|c|}
\hline & & $\begin{array}{c}\text { Fair value } \\
\text { measurements } \\
\text { complexity }\end{array}$ & $\begin{array}{l}\text { Audit } \\
\text { quality } \\
\text { practice }\end{array}$ \\
\hline \multirow[t]{3}{*}{$\begin{array}{l}\text { Fair value measurements } \\
\text { complexity }\end{array}$} & $\begin{array}{c}\text { Pearson } \\
\text { Correlation }\end{array}$ & 1 & $.539 * *$ \\
\hline & Sig. (2-tailed) & & .000 \\
\hline & $\mathrm{N}$ & 285 & 285 \\
\hline
\end{tabular}

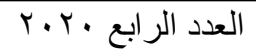


Analytical Analysis for the Impact of Fair Value Accounting on Audit ...

Aya Ashraf Mahmoud Mohammed

\begin{tabular}{|l|c|c|c}
\hline Audit quality practice & $\begin{array}{c}\text { Pearson } \\
\text { Correlation }\end{array}$ & $\mathbf{. 5 3 9 * *}$ & 1 \\
\cline { 2 - 4 } & Sig. (2-tailed) & .000 & \\
\hline $\mathrm{N}$ & 285 & 285 \\
\hline
\end{tabular}

**. Correlation is significant at the 0.01 level (2-tailed).

Source : Results of statistical analysis ( SPSS)

It is concluded from the previous table, there is a direct relationship between fair value measurements complexity and audit quality practice at the level of significance of $1 \%$, as the value of the coefficient $(\mathrm{R})$ between them has a value of $(0.539)$. As a result, the two variables have a positive relationship of $53.9 \%$, which means that whenever the financial statements preparers and external auditors pay attention to fair value measurements complexity; this will lead to an increase audit quality practice.

B: Regression Analysis between variables: the results reached the following table:

Table (5) Direct impact of fair value measurements complexity and audit quality practices $(\mathbf{n}=\mathbf{2 8 5})$

\begin{tabular}{|c|c|c|c|c|c|c|c|c|}
\hline & $\begin{array}{c}\text { S. of } \\
\text { Squares }\end{array}$ & Df & $\begin{array}{c}\text { M. } \\
\text { squares }\end{array}$ & F. & Sig. & R & $\mathbf{R}^{2}$ & $\begin{array}{c}\text { Adjusted } \\
\mathbf{R}^{\mathbf{2}}\end{array}$ \\
\hline Regression & 24.346 & 1 & 24.346 & 115.738 & 0.000 & .539 & .290 & .288 \\
\hline Residual & 59.531 & 283 & .210 & & & & & \\
\hline Total & 83.877 & 284 & & & & & & \\
\hline
\end{tabular}

\section{Source: Results of statistical analysis (SPSS)}

It is clear from the previous table that: 
Analytical Analysis for the Impact of Fair Value Accounting on Audit ...

Aya Ashraf Mahmoud Mohammed

The size of the research sample is (285). Therefore the results are consistent with the results of the descriptive statistical analysis and there are no missing values, as the degrees of freedom are (284) because it is (the size of the community - 1.) $(\mathrm{N}-1)$. The significance of the regression model at $5 \%$ level of significance, because the significance value came $(0.000)$, which is a value less than $5 \%$ and achieves the highest degree of significance for the model. Therefore, the regression model is fully accepted for the first hypothesis. The correlation coefficient between the two variables is $(\boldsymbol{R}=\mathbf{0 . 5 3 9})$, which means that the relationship between the independent variable (fair value measurements complexity) and the dependent variable (audit quality practices) is positive and direct relationship with a percentage $53.9 \%$ and this result is consistent with the results of the correlation analysis. The value of the $\left(\boldsymbol{R}^{2}\right)$ between the two variables was (0.290), while the adjusted value was (0.288). In general, the first hypothesis can be judged that the alternative hypothesis is accepted, and the null hypothesis is not accepted, which means that it is fair value measurements complexity significantly and positively affects audit quality practices. Therefore, the regression equation can be formulated in the following image:

$$
\begin{gathered}
\mathrm{Y}=\mathrm{a}+\boldsymbol{\beta} \mathrm{X}_{1}+\mathrm{e} \\
\mathrm{Y}=1.771+.477+.044
\end{gathered}
$$

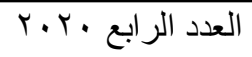


Analytical Analysis for the Impact of Fair Value Accounting on Audit ...

Aya Ashraf Mahmoud Mohammed

Note:

$\mathbf{Y}=$ audit quality practices, $\mathbf{X}_{1=}$ fair value measurements complexity, $\mathrm{a}=$ Constant, $\mathrm{\beta}=$ regression coefficient, $\mathrm{e}=$ Standard error.

H2: Fair value disclosure significantly and positively affects audit quality practices.

It is clear from this hypothesis that there are two types of variables, namely:

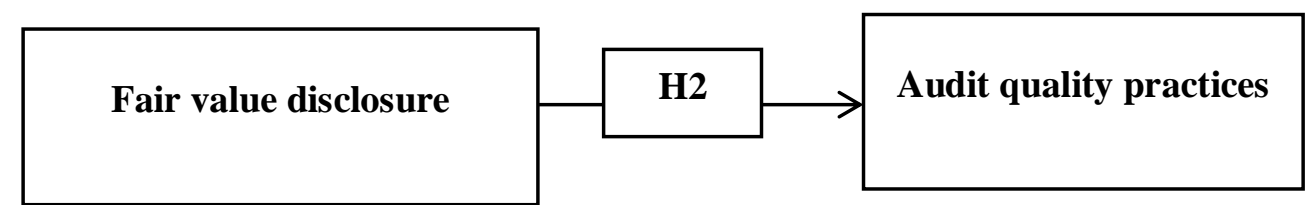

A- Correlation Matrix:

Table (5.14) Correlation Matrix between Fair value disclosure and Audit quality practice_(n=285)

Correlations

\begin{tabular}{llr|r} 
& & \multicolumn{1}{c|}{$\begin{array}{c}\text { Fair value } \\
\text { disclosure }\end{array}$} & \multicolumn{1}{c}{$\begin{array}{c}\text { Audit quality } \\
\text { practice }\end{array}$} \\
\hline Fair value disclosure & Pearson Correlation & 1 & $\mathbf{. 5 5 0}^{* *}$ \\
\cline { 2 - 4 } & Sig. (2-tailed) & & .000 \\
\cline { 2 - 4 } Audit quality practice & $\mathrm{N}$ & 285 & 285 \\
\cline { 2 - 4 } & Pearson Correlation & $\mathbf{. 5 5 0 * *}$ & 1 \\
\cline { 2 - 4 } & Sig. (2-tailed) & .000 & \\
\hline & $\mathrm{N}$ & 285 & 285 \\
\hline
\end{tabular}

**. Correlation is significant at the 0.01 level (2-tailed).

It is clear from the previous table that, there is a significant and positive correlation between Fair value disclosure and Audit quality practice at a level of significance of $1 \%$, where the 
Analytical Analysis for the Impact of Fair Value Accounting on Audit ...

Aya Ashraf Mahmoud Mohammed

correlation coefficient reached $(\boldsymbol{R})(0.550)$, which means that there is a relationship between the two variables at a rate of $55 \%$, and this means that the interest of financial statements preparers and external auditors in the variable Fair value disclosure will lead to an increase Audit quality practices.

B: Regression Analysis between variables: The results reached the following table:

Table (6) Direct impact of Fair value disclosure and Audit quality practice $(n=285)$

\begin{tabular}{|c|c|c|c|c|c|c|c|c|}
\hline & $\begin{array}{c}\text { S. of } \\
\text { Squares }\end{array}$ & Df & $\begin{array}{c}\text { M. } \\
\text { squares }\end{array}$ & F. & Sig. & $\mathbf{R}$ & $\mathbf{R}^{\mathbf{2}}$ & $\begin{array}{c}\text { Adjusted } \\
\mathbf{R}^{\mathbf{2}}\end{array}$ \\
\hline Regression & 24.346 & 1 & 24.346 & 115.738 & 0.000 & .539 & .290 & .288 \\
\cline { 1 - 3 } Residual & 59.531 & 283 & .210 & & & & & \\
\cline { 1 - 3 } Total & 83.877 & 284 & & & & & & \\
\hline
\end{tabular}

\section{Source: Results of statistical analysis (SPSS)}

It is clear from the previous table that:

The significance of the regression model is at the level of $5 \%$ significance, where the value of $(F=122.766)$ with a significant value (0.000) is less than the level of significance, which means acceptance of the model. The existence of a positive and direct correlation between Fair value disclosure and Audit quality practice, according to the findings of the correlation matrix, where the value of the coefficient $(\boldsymbol{R}=\mathbf{. 5 5 0})$ means the existence of a relationship between the two variables by $55 \%$. The interpretation coefficient reached $\left(\boldsymbol{R}^{2}=.303\right)$ while the adjusted value reached (.300). 
Analytical Analysis for the Impact of Fair Value Accounting on Audit ...

Aya Ashraf Mahmoud Mohammed

According to the above, The previous results and acceptance of the regression model, the null hypothesis is rejected and the alternative hypothesis is accepted that states Fair value disclosure significantly and positively affects audit quality practices. Therefore, the regression equation can be formulated as follows:

$$
\begin{gathered}
\mathrm{Y}=\mathrm{a}+\boldsymbol{\beta} \mathrm{X}_{2}+\mathrm{e} \\
\mathrm{Y}=1.912+.493+.045
\end{gathered}
$$

Note:

$\mathbf{Y}=$ audit quality practices, $\mathbf{X}_{2}=$ Fair value disclosure, $\mathrm{a}=$ Constant, $\beta=$ regression coefficient of the independent variable, $\mathrm{e}=$ Standard error .

\section{Section Three: Conclusion}

Auditors will be interested in these findings because they address the practices should be performed by auditors to ensure that fair value measurements are free from management's manipulation and misstatement. Correlation coefficient, regression analysis, Cronbach's alpha coefficients, Shapiro-Wilk method and Kolmogorov-Smirnov method were conducted to test hypothesis. The hypothesis supports that fair value measurements complexity significantly and positively affects audit quality practices. This means that fair value measurements complexity; leads to an increase audit quality practices.

\section{Future Research}

The study provides some future recommendations: 
Analytical Analysis for the Impact of Fair Value Accounting on Audit ...

Aya Ashraf Mahmoud Mohammed

1. The finding of this study is limited on financial instruments measured and disclosed using fair value. Future research may be more focused and study the impact of fair value measurements and disclosure for derivatives on audit quality practices.

2. The finding of this study is limited on some audit quality practices such as: professional skepticism and due professional care. Future research may take in considerations other audit quality practices.

\section{References}

1. Abdallah, S., 2018. "External auditor type, discretionary accruals and investors' reactions". Journal of Accounting in Emerging Economies, 8(3),352-368

2. Abdullatif, M., 2016. "Auditing Fair Value Estimates in Developing Countries: The Case of Jordan". Asian Journal of Business and Accounting, 9(2), 101-140.

3. Akbar, M. S., \& Suraida, I., 2017. "Competence and Professional Care of External Auditor on Information Technology Audit". Trikonomika, 16(1), 21-27.

4. Aouni, B., McGillis, S., \& Abdulkarim, M. E., 2017. "Goal programming model for management accounting and auditing: a new typology". Annals of Operations Research, 251(1-2), 41-54.

5. Bedard, J. C., Johnstone, K. M., \& Smith, E. F., 2010. “Audit quality indicators: A status update on possible public disclosures and insights from audit practice". Current Issues in Auditing, 4(1), C12-C19.

6. Bratten, B., Gaynor, L. M., McDaniel, L. S., Montague, N. R., \& Sierra, G. E. , 2013. "The audit of fair values and other estimates: The effects of underlying environmental, task, and auditor-specific factors". Auditing:

A Journal of Practice \& Theory, 32, 7-44. 
Analytical Analysis for the Impact of Fair Value Accounting on Audit ...

Aya Ashraf Mahmoud Mohammed

7. Cannon, N. H., \& Bedard, J. C., 2017. "Auditing challenging fair value measurements: Evidence from the field". The Accounting Review, 92(4), 81-114.

8. Chiang, C., 2016. "Conceptualising the linkage between professional scepticism and auditor independence". Pacific Accounting Review.

9. Christensen, B. E., Glover, S. M., Omer, T. C., \& Shelley, M. K., 2016. "Understanding audit quality: Insights from audit professionals and investors". Contemporary Accounting Research, 33(4), 1648-1684.

10. Cruz, A. L. D., Patel, C., Ying, S., \& Pan, P., 2020. "The relevance of professional skepticism to finance professionals' Socially Responsible Investing decisions". Journal of Behavioral and Experimental Finance, 100299.

11. Feng, M., \& Li, C., 2014. "Are auditors professionally skeptical? Evidence from auditors' going-concern opinions and management earnings forecasts". Journal of Accounting Research, 52(5), 10611085.

12. Hoos, F., Pruijssers, J. L., \& Lander, M. W., 2019. "Who's watching? Accountability in different audit regimes and the effects on auditors' professional skepticism”. Journal of Business Ethics, 156(2), 563-575.

13. Hussin, S. A. H. S., Iskandar, T. M., Saleh, N. M., \& Jaffar, R. 2017. "Professional skepticism and auditors' assessment of misstatement risks: the moderating effect of experience and time budget pressure". Economics \& Sociology, 10(4), 225-250.

14. International Accounting Standards Board, 2014. IFRS 9: Financial Instruments.

15. International Auditing and Assurance Standards Board, 2008. Auditing Accounting Estimates, Including Fair Value Accounting Estimates, and Related Disclosures, International Standard on Auditing 540, International Auditing and Assurance Standards Board, New York, NY. 
Analytical Analysis for the Impact of Fair Value Accounting on Audit ...

Aya Ashraf Mahmoud Mohammed

16. Lau, C. K., 2016. "How corporate derivatives use impact firm performance?". Pacific-Basin Finance Journal, 40, 102-114.

17. Maksymov, E. M., \& Nelson, M. W., 2017. "Malleable standards of care required by jurors when assessing auditor negligence". The Accounting Review, 92(1), 165-181.

18. Nearon, B. H., 2005. "Foundations in auditing and digital evidence". The CPA Journal, 75(1), 32.

19. Nelson, M. W., 2009. "A model and literature review of professional skepticism in auditing". Auditing: A Journal of Practice \& Theory, 28(2), 1-34.

20. Nwanyanwu, L. A., 2017. "Audit Quality Practices and Financial Reporting in Nigeria". International Journal of Academic Research in Accounting, Finance and Management Sciences, 7(2), 145-155.

21. Palea, V., 2014. "Fair value accounting and its usefulness to financial statement users". Journal of Financial Reporting and Accounting, 12(2), 102-116.

22. Popova, V., 2013. "Exploration of skepticism, client-specific experiences, and audit judgments". Managerial Auditing Journal.

23. Singh, J.P., \& Doliya, P., 2015. "On the audit of fair value measurements". Economic Horizons, 17(1), 59-69.

24. Stevens, E., Moroney, R., \& Webster, J. , 2019. "Professional skepticism: The combined effect of partner style and team identity salience". International Journal of Auditing, 23(2), 279-291.

25. Tahat, Y., Dunne, T., Fifield, S., \& Power, D., 2016. "The value relevance of financial instruments disclosure: evidence from Jordan". Asian Review of Accounting.

26. Volarević, H., \& Varović, M., 2018. 'Internal model for IFRS 9expected credit losses calculation". Economic Review, 69(3), 269-297. 